\title{
Commentaire sur l'ouvrage de Jean-Pierre Darre
}

L'invention des pratiques dans l'agriculture. Vulgarisation et production locale de connaissances, 1996, Paris, Khartala (préface de Jean-Pierre Chauveau)

\section{Philippe Geslin}

\section{OpenEdition}

Journals

Édition électronique

URL : https://journals.openedition.org/tc/435

DOI : $10.4000 /$ tc. 435

ISSN : 1952-420X

Éditeur

Éditions de l'EHESS

Édition imprimée

Date de publication : 1 octobre 1998

ISSN : 0248-6016

Référence électronique

Philippe Geslin, « Commentaire sur l'ouvrage de Jean-Pierre Darre », Techniques \& Culture [En ligne], 30 | 1998, mis en ligne le 28 octobre 2005, consulté le 29 septembre 2022. URL : http://

journals.openedition.org/tc/435; DOI : https://doi.org/10.4000/tc.435

Ce document a été généré automatiquement le 29 septembre 2022

Tous droits réservés 


\section{Commentaire sur l'ouvrage de Jean- Pierre Darre}

L'invention des pratiques dans l'agriculture. Vulgarisation et production locale de connaissances, 1996, Paris, Khartala (préface de Jean-Pierre Chauveau)

Philippe Geslin 